Received: 16 March 2020

Accepted: 4 May 2020

Keywords: Cultural legacy; gravestone; memory; naming; necronominalism; political erasure

\section{Exploring Genealogy's Necronominalism}

\author{
Stephen B. Hatton
}

Abstract: This article explores the relation of genealogy and necronominalism, or naming the dead. It discusses funerary practices as a recapture of the dead, gravestones as complex signs, and memory and death including a memento mori and a liber memorialis. An authentic search for the dead involves considering the cultural legacy they left. The article suggests that genealogy charts are modeled after historical consciousness which is formed on the basis of naming the dead. Naming and learning about the dead help some people gain or deepen their sense of identity. Naming the dead reverses the oblivion into which the forgotten dead disappear. Genealogy works in the opposite direction as political erasure. Genealogical research is essentially a practice that names the dead which enables the researcher to include an ancestor, relative, or research subject on genealogy charts and in the cultural world of the living. But genealogy is also sometimes used as an exclusionary power tactic.

\title{
Introduction
}

Genealogists name ancestors and people in their ancestral families. An unnamed ancestor cannot be written on a pedigree chart and does not yet belong to one's family or family tree. Naming is essential to genealogy. Those named are almost all dead so naming the dead, or necronominalism, underlies the practice of genealogy. The goal of this article is to explore the connection between genealogical naming and the dead. It will journey through burials, gravestones, memories, cultural legacy, research, and more.

\section{What is a name?}

There have long been philosophical discussions and disagreements about what a personal name is. Generally when one speaks, writes, or thinks of a name one is referring to a unique identity in the world though there may be multiple people with the same name. Nineteenthcentury British philosopher John Stuart Mill thought of a proper name as whom or what one speaks about without describing anything about the referent (the person, concept, or object referred to). ${ }^{1}$ German philosopher Gottlob Frege pointed out that proper names can refer to imaginary and nonexistent entities and that two people can use the same name to identify the same being but in different senses. ${ }^{2,3}$ The theory of a proper name called descriptivist contends that rather than referring to one object, or referent, it refers to a set of propositions that uniquely describe it. ${ }^{4}$ The causal theory holds that a personal name refers to one individual because social groups associate that name with a person in a naming event such as a christening. ${ }^{5}$ The direct reference theory holds that a proper personal name refers to a specific person without carrying other connotations about the person (such as making value judgments or reflecting positive or negative biases), similar to Mill's view. ${ }^{6}$

In this article it is not necessary to choose one of these theories. It is sufficient to state that when genealogists write or speak a person's name they are referring to a unique identity with relational attributes that permit them to place that person on a pedigree chart and family group sheet. Of course genealogists seek to discover vital data for that person, and curious researchers will try to find out more information about the individual.

Naming is social in nature. It is what a person is called by social groups-a circle of friends, co-workers, churchgoers, neighbors, and others. A baby is not fully accepted into a family or society at the time of biological birth but at the time of receiving a name. ${ }^{7}$ 


\section{Recapture of the dead in funerary practices}

A funeral is a time to remember the person who died, to emotionally support those who are grieving, and to restore the social group from the damage that death causes. ${ }^{8,9}$ Funerary practices in various cultures help people master emotions and assist in returning to normality. ${ }^{10}$ At funerals the name of the dead person is spoken and written in the context of a departure from society.

In some cultures objects owned by or associated with the deceased are produced, exchanged, or consumed at funerals. Those objects evoke the presence of the dead person and physically help attendees to connect with, remember, and identify with the departed. Artefacts evoke social memories by metaphorically alluding to aspects of the deceased. ${ }^{11}$

Funerary rituals affirm the absence of the deceased ${ }^{12}$ and allow mourners to reanimate the lost presence through objects but also by remembering and speaking the name of the departed. One can also view this from another perspective: the beloved object that belonged to the deceased person is reanimated by the absent presence of the deceased. ${ }^{13}$ Burial serves to facilitate the dead to live with the living. ${ }^{14}$ By acknowledging the departure of the living person from one's social circle and yet remembering the importance of that person's life, one assimilates that now-dead person into one's still-living life and social groups. In some cultures, objects owned by or closely associated with the deceased are buried with the person. ${ }^{15}$ In others, the dead were buried under the houses of relatives. ${ }^{16}$ The physical burial location near relatives is an early historical construction of ancestorhood. ${ }^{17}$ In some modern cases, dead people of renown, particularly politicians, are publicly displayed in an effort to prolong their influence of authority (for example, Vladimir Lenin). ${ }^{18}$ Reburials are sometimes of political importance and well-attended (for example, Imre Nagy, prime minister of Hungary in 1956). Sometimes religious relics are of particular value (for example, relics of St. Francis of Assisi).

\section{Gravestones}

Similar to how a name refers to an individual, a gravestone references the body below it. The body is hidden below the surface of the earth that supports the gravestone which is its sign. ${ }^{19}$

The significant connection between a gravesite, its role as a sign for the departed person, and writing is preserved in the etymology of the word "sign." In classical Greek the word sēma, from which the English word semaphore derives, meant both sign and grave. ${ }^{20,21,22}$ In Koine $\mathrm{Greek}_{1}{ }^{23}$ the verb form also meant to write. Because of that the grave marker points to itself and the burial plot. The gravestone stands for what it stands in (a burial ground). Put differently, the gravestone is a sign that signifies the source of the signification. ${ }^{24}$ Following this thought, the gravestone with the name engraved on it is a marked reference to that which has passed-it points to its own passing. The signified person's passing is the meaning of the stone. Put differently, the marker refers not just to the person who passed but to the passing itself. ${ }^{25}$ It would not exist had the person not passed from life to death. It has power because it is a place (in space) where time turns to the past. ${ }^{26}$ It is a "mortalization of time that give place its articulated boundaries." ${ }^{27}$ The name on the stone is essential to its specific role as a sign.

Adding to this significance, the corpse is a sublated self, a philosophical term used by Hegel quite applicable here. ${ }^{28,29}$ The self has left the body, and the stone signifies the body and the departed person. Sublation (Aufhebung) for nineteenth-century German philosopher G. W. F. Hegel abolishes, preserves, and advances a dialectical process, a process of conceptual development. In that dialectic negation (in this case death contrasted with life) is the impetus in the unfolded beginning (entfaltete Werden) ${ }^{30}$ (in this case a person folded from life to death) who is preserved in memory and referenced in and by the gravestone. The beginning of the dialectic is the death of the person. But whereas in death and burial the corpse is the sublated self (in a sense the self leaves the body at death but also leaves social connections), in the genealogical dialectic, reading the name of the deceased on the gravestone and naming the deceased recognize death, preserve memory, and restore the dead person to a proper place in the family, community to which the person belonged, and cultural legacy. The genealogist participates in the dialectic by helping to return the departed self to the family narrative but also to the memory of the deceased as part of a community and culture.

The stone was created as a result of the demise and burial of the person. The engraved name and the gravestone were co-erected as the referrer and its reference. The production and placement of the marker create a reminder and memory of the named buried person. ${ }^{31}$ Naming implies memory. Naming by those lacking first-hand memory of the signified enables a recapture of the person by means of the stone erected by those who remembered and usually grieved at the loss of the buried beloved. Personal memories of the deceased person disappear with the deaths of those who knew the living person, and so the absence of the buried person and those who grieved at the loss, through their absence, become present in the memorial—the memorial with an engraved name. The materiality of monuments gives them mnemonic status. $^{32,33}$ It is the physical nature of a monument that creates and sustains memory of the person about whom it was erected. Memorials become monuments when mourning is complete. ${ }^{34}$ 
The gravestone is iconic because it marks the presence of an absence. ${ }^{35,36}$ And while the corpse is lacking life and embodies the absent presence, it is the very presence of that absence that is marked by the gravestone, and by extension, the genealogist reading and recording the name from the engraving brings to presence the now-deceased ancestor. The noting of the dead ancestor will not contain the same emotions and details as those who buried the person but the essential point here is that the engraved name of the deceased brings that person to presence It is in the act of naming that recaptures the person. The genealogist visits the burial plot to make the deceased live, and so remembered in this way the dead one comes to life. The grave marker or cenotaph placed there by one or more mourners is a sign of bereavement ${ }^{37}$ but becomes a sign of the departed, of remembrance, and of presence. ${ }^{38}$ While a physical stone cenotaph refers to a person, a name may also be a cenotaph for the person whose name it was. ${ }^{39}$ That is, the name of the person becomes a representation of the dead person in the function of a cenotaph. In that case, the name may become a numinous revisitation of history.

Thus the gravestone is deictic, or an indexical sign, in that its signification depends on where it is. ${ }^{40}$ It points downward in space as it points backward in time. Gravestones piled to one side of the cemetery do not clearly show their reference. They suggest only that the person whose name is engraved on the stone is buried somewhere in the cemetery.

While most often someone's social geography is oriented around a home or a place of employment, it may also be centered on a graveyard in which the beloved lies. The final resting point is a place of orientation. ${ }^{41}$

\section{Death and memory}

Memory of someone dead brings an absent one to presence. ${ }^{42} \mathrm{~A}$ monument refers to an absence that is a presence in memory. ${ }^{43}$

\section{Memento mori}

The memory or presence of an ancestor may be triggered by an object as well as by writing on a gravestone. The presence of an ancestor lingers on in the object the ancestor owned and used. ${ }^{44}$ The object projects and emits a history largely through its association with the deceased. This may be especially evocative with objects connected to the body (for example, combs and jewels) or the inner life (for example, memoirs and diaries). ${ }^{45}$ Material objects owned or used by the person or that contain writing of the person or that have an image of the person (photographs, paintings, drawings) bring a visceral connection to that person. That is because of the association of the object to the departed, the attachment of the descendant and the departed, and the transference of the sense of belonging of the object to oneself. Material objects used by the departed are not symbolic but sensuously insist themselves on people because they are physical traces of the past. ${ }^{46}$ These may serve like a memento mori common to some cultures. They invoke a unique deceased individual whose name is attached to one or more objects. ${ }^{47}$ Material culture helps to materialize remembering. ${ }^{48}$ In some cases, a material object becomes a fetish, an inanimate object inhabited by the presence of the individual who owned it. ${ }^{49}$ Memorials may also become fetishized. ${ }^{50}$

An advancement for understanding the connection of an object with a person becoming a fetish was made by Karl Marx who explored the fetishism of objects from the perspective of commoditization. Wood may be made into a table as a product of labor and then placed into the marketplace as a commodity to be exchanged for money. In that act the sensuous qualities of the wood get pushed into the background and are replaced by the social relations of the object: "the commodity-form, and the value-relation of the products of labour within which it appears, have absolutely no connection with the physical nature of the commodity." the peculiar social character of the labour which produces them." ${ }^{\prime 52}$ The labor- and social-values are independent of the sensuous qualities of the material object.

This fetish-object can become a form of reification. Though originally used in the context of a Marxist critique of capitalism ${ }^{53,54}$ the term reification now extends its use to refer to the objectification of a human from something non-human, for example, the cane used so often by Charlie Chaplin that it came to "stand for" him..$^{55}$ The reifying object replaces or displaces the now absent reified so becomes, in effect, a rematerialization. In spite of the absence of the displaced person, the reified object brings a remembrance, or presence, of the absent. The object is tied to the name of the former owner. Without naming the deceased person there is less likelihood of reification. Object and name are linked, just as death is linked with object and name.

\section{Liber memorialis}

In the Middle Ages names were recorded in codices. By the eighth century ancient necrography (writings, or recordings, of lists of dead people) had been overthrown in most of Europe. ${ }^{56}$ The dead had moved into cities, towns, and churches. In the ninth century the Benedictine Abbey at Reichenau on Lake Constance compiled the monastic liber memorialis. In it were recorded 40,000 names of the deceased. ${ }^{57}$ Also in the ninth century names of the dead were recorded in necrologies sometimes for religious reasons. ${ }^{58}$ This reflected the close connection between naming the dead and memory, and between death and naming. 


\section{Cultural legacy}

Our awareness of death often arises from consideration of our origin..$^{59}$ Where did we come from? This origin question is not just genealogical but cultural. Those who came before us gave us a linguistic, legal, political, institutional, social, cultural (literary, artistic, etc.), and historical legacy. ${ }^{60}$ Our thinking is influenced by this legacy. We practice and follow customs created by those who passed on this legacy-our deceased forebears. This is a necessary component of transmitting the legacy of cultural institutions. ${ }^{61,62}$ It, as well as existential concerns and personal loss, is an important source of our awareness of death. In spite of our continual drive toward innovation and changes to our beliefs and practices, we live in a world created by our predecessors. In this sense the dead live on in our world. ${ }^{63,64}$ They give meaning to our lives. ${ }^{65}$ Genealogy is one way to learn more about those who gave us this cultural legacy and to name them. The sublated self discussed earlier is left behind in a corpse that was buried in a grave, is pointed to by a stone, and has an absent presence preserved in the naming by a genealogist. A genealogist gives context of records of the deceased found in vital records and burial registers.

During the Mexican Día de los Muertos (Day of the Dead, which spans three days), people build ofrendas (altars) at the gravesites of ancestors and in their houses to honor the dead and to celebrate them. Using calaveras (skulls, often made of sugar), pan de muerto (a kind of sweet bread), atole (drink made of masa and elote, dough and corn), marigolds, but also photos and favorite foods and beverages of the deceased, and belongings closely associated with them, participants create a festive occasion. They string a papel picado (paper banner) and exhibit alebrijes (underworld fantastic creatures). All of these are an invitation to the honored dead to return and join in the celebration. Family members frequently relate humorous anecdotes in which the dead person was involved while alive. Derived from Aztec customs, these celebrations treat the dead as living with the living. More recently, in some regions people dress up as if dead, and so the dead and the living meet half-way. ${ }^{66,67,68,69,70,71}$

\section{Historical consciousness and genealogy charts}

Historical consciousness is formed partly on the basis of the names of the dead of significance to someone and on conceptualization of the dead. ${ }^{72}$ It is formed from one's relation to them from the perspectives of ascent and descent.

Genealogy charts model the perspectives. ${ }^{73,74}$ How one conceives of and depicts ancestry and genealogy shapes history. ${ }^{75}$ A chart can depict oneself as the root with ancestors fanning up or out from oneself as in a pedigree chart (Ahnentafel). One can also depict an ancestor as the progenitor of descendants spreading down as on a descendants chart.

\section{Identity}

Naming dead ancestors and writing their names on a pedigree chart may help the researcher find his/her own identity. ${ }^{76,77,78,79}$ One learns about oneself and who one is as a result of learning about one's origins. Names help place one in a context of the present as well as past. Names and basic vital data enable further research that may help supply other information such as ethnicity, countries of origin, geography, religion, occupation, and one's place in culture and history. Further research gives more information about who one is and where one came from -it gives one a better sense of genealogical, social, and personal identity. Naming and the practice of memory constitute identity. ${ }^{80}$

\section{Reversing disappearance}

If we do not remember and name the dead we cease living historically and culturally. While it is debatable whether naming the dead is part of human nature, it is part of the core practice of genealogy. German philosopher Hans-Georg Gadamer wrote that humans seek to abide with the dead. ${ }^{81}$ Not naming allows the dead to disappear into oblivion thereby removing the ground and basis of our cultural beliefs and practices. To avert this oblivion one must name the deceased (on gravestones, on genealogical charts and narratives, and elsewhere) and care for those names so that they are remembered. ${ }^{82}$ We care for their corpses and gravestones and we should also care for their names. Naming the dead serves a similar function as the gravestone that points downward to the corpse and backward in time-to grief, to love, and to loss. Names of the dead as well as stones commemorating the dead establish a point at which the dead and the living become related. ${ }^{83}$ This permits the re-integration of the dead into the world of the living ${ }^{84}$ and allows the absent to become present.

\section{Political erasure and the death of death and naming}

The role of genealogy in naming the dead and remembering by naming is starkly contrasted with political regimes that have the objective to do the opposite. Banu Bargu summarizes political disappearances that occurred and occur in Turkey. ${ }^{85}$ Many similar cases occurred and occur in parts of Latin America and throughout the world. Perhaps the first official modern documentation of this kind of disappearance used as a state tactic was in Nazi Germany. ${ }^{86}$ This occurred in the 1941 Hitler Nacht und Nebel decree ordering the covert removal of citizens suspected of political activism and resistance. 
Execution of this state tactic is meant to create fear and intimidation to force the populace to submit to sovereign power and to cease resistance, opposition, and protests against the policies of state power. This extralegal violence has become constitutive of sovereignty. ${ }^{87}$

Political disappearance, or erasure, consists of forcible removal of people in secret, detention often accompanied by torture, and an unknown fate. The state erases the social and political existence of the disappeared. ${ }^{88}$ There remain no bureaucratic records of the person, no funerals, no memorials, ${ }^{89}$ and no bodies unless mass graves are discovered later. Except for the fact that this now happens to social classes, religions, ethnic groups, etc., it is much like what occurred to disgraced dead sovereigns in imperial Rome. If a deceased sovereign in imperial Rome received the punishment of damnatio memoriae all traces of his existence were erased. ${ }^{90}$ Inscriptions about him on tablets were destroyed, faces modeled after his likeness were chiseled from statues, his temples were destroyed, his image on coins was defaced, his will was annulled, and his property was expropriated.

As Arthur Bradley summarizes it, it is as if he never existed. ${ }^{91}$ Applied to twentieth-century cases, Bargu calls this invisibilization. ${ }^{92}$ Individuals' bodies are erased. Bradley argues that this rewrites and undoes the past as if those politically erased were made to be "unborn," "unlived," and "undied." ${ }^{93}$ If a sovereign deems a person or social group to think or act in a way that threatens the sovereign's sovereignty, in short, is politically intolerable to the state, then that person or substantial portion of that group is forced to become ontologically nonexistent. ${ }^{94}$ The person returns to nothing - to a time before the person was born. That is an extreme position against the fixedness of history, recalling eleventh-century theologian Peter Damian's view that "God can cause things that have happened, not to have happened." ${ }^{95}$

Political erasure leads to the death of death which implies the death of the birth and life of the now-erased death. The person is unrecapturable because the times of his/her death, birth, and life are invisible. This non-death is the most profound kind of death. ${ }^{96}$ This points out a fundamental opposition between genealogy's drive toward necronominalism and sovereignty's drive to erase those who politically contest the sovereign's attempts to enforce submission.

\section{Genealogical research}

Discovering an ancestor initially consists of naming the person. When the genealogical researcher first discovers the ancestor, the ancestor is named. This is quite different than a historian discovering a previously unknown fact. The historian practices with goals and methodologies related to but different than those of genealogy. Among the key differences is that while genealogy is concerned with identifying individuals in specific relations with others, history is not. ${ }^{97}$ Naming the ancestor is evidence that one has discovered who the ancestor was. Thus necronominalism (in the sense of naming the dead) underlies genealogical discovery and practice. ${ }^{98}$

Naming's importance to non-genealogists may be seen in epigraphs the use of which increased after the Reformation, and that were used more frequently in the nineteenth and twentieth centuries. ${ }^{99}$ We have lived now for some time in the era of the necronym in which a baby is named after someone who has died. This practice is grounded in memory. ${ }^{100}$ Some religions practice naming babies after a beloved relative. In some cultures and religious denominations as well as political eras children were named following a customary onomastic pattern of naming after parents, parents-in-law, and siblings.

\section{Genealogy as exclusionary power}

There is another side to doing genealogy for many people. When filling out a pedigree chart a genealogist includes people and very often, by extension, the social groups to which they belonged. Social groups may be viewed in terms of race, ethnicity, economic class, religion, and others. This is the inclusionary perspective of genealogy illustrated by researchers who are proud of their heritage and elevate their own selfworth by identifying with those ancestors and sometimes elevated classes of ancestors as conceived by the researcher. The other side is that genealogy is often practiced as exclusionary as has been argued by scholars such as Catherine Nash who wrote about how linguistic geneticization of kinship and identity "slips from individual and family to wider notions of collective identity, origins and communities of descent, meeting racialized versions of difference and belonging as it does so." Other scholars have made related observations. ${ }^{101,102,103,104,105}$ In some of these cases, pedigree charts and genealogists' self-images exclude certain races, ethnicities, social and economic classes, etc. Those included are often deemed superior. Those who are excluded are too often viewed as inferior. The genealogical method gets used as an instrument of power. ${ }^{106}$ One excludes what troubles one's self image, and one excludes what one wants to dominate with power, make invisible, and cause to disappear. ${ }^{107}$ Genealogy as a discipline should call attention to this danger, an uncomfortable and difficult task. Whereas these urges to make disappear are sometimes cultural ("somewhere every culture has an imaginary zone for what it excludes, and it is that zone we must try to remember"108), at other times they are part of the unexamined practices of some genealogists.

A case in point is that in spite of proving via a Y-chromosome test that U.S. president Thomas Jefferson was the father of a son of his slave Sally Hennings, the Monticello association of Jefferson descendants disputed the genealogical implications in what was a racialized application of 
heritage, or kinship. ${ }^{109,110}$ This alerts us to the need for genealogy to explore this aspect of itself and the ethical issues involved with exclusionary power and biological views of kinship.

Another example is that after proving her Native American heritage, Heather (last name anonymized) became a member of the Pocahontas society. Later she was removed from that society when it learned that she was also of African-American heritage. ${ }^{111}$

Direct-to-consumer genetic testing touting "deep ancestry" makes imprecise, unfounded, and misleading claims based on assumptions about the overlay of race, ethnic heritage, geography, and genealogy. Encouraged by the advertising of the suppliers of the genetic test kits, those who take the tests search for identity without understanding what identity is.

\section{Genealogical practitioners}

Regardless of their experience level, those who practice genealogy name their ancestors or research subjects. Doing genealogy requires naming the dead. Beginners and those with little experience or training in research standards, techniques, and methods often have as their only goal entering names onto a pedigree chart where they are missing. Many do this with insufficient or no evidence and even in the face of contrary evidence. They copy from other carelessly filled-out pedigree charts and infrequently seek trustworthy original sources or use sound reasoning. Most of their data are noted without citation or reliable cited sources.

When filling in names is the only goal it becomes more likely to commit same-name-same-person errors in which multiple people are conflated. Fathers are sometimes born after their children, strangers are made grandparents, and great grandparents lived their entire lives in countries, states, or counties different from where their children were conceived and born. The urge for these collectors of names is to name the dead even if the dead were unrelated.

This form of necronominalism has ramifications. It results in inaccurate pedigrees that give one a false view of ancestry and misleads other researchers. This approach to genealogy has no regard for truth and the ethical imperative of truth. ${ }^{112}$ Moreover it dishonors the dead by misplacing them in place, time, and relationships. It displaces them from their authority and identity, makes legitimate forebears disappear, fails to bring ancestors to presence, and makes it more difficult for the disappeared absent ones to reappear. For these reasons it fails to presence descendants' ancestors, sends ancestors into oblivion, and prevents descendants from claiming their legacy.

Experienced genealogists work to identify correct names, years, and locations in vital and other records. They follow standards and use appropriate proven methods, and this most often leads to correct identification of the named people. They too have the goal of naming the dead but understand the importance of identifying the correct dead people before entering them onto a pedigree chart or family group sheet.

Genealogy would be strengthened if more of its practitioners understood the significance of the legacies left by named (and unnamed) ancestors. Each named person was part of a community and served a role in passing on a cultural legacy. Understanding this and learning from non-genealogical scholars who study and write about these topics can enrich genealogy by, among other things, recognizing the roles of authority and historicity. Institutions are historically inherited. Giving voice to the dead with emphasis on how they expressed their ideas and thoughts in language and actions enables genealogy to deepen the sense of identification and attunement with what was inherited or culturally passed on. In our language we speak with the words of the dead and the dead speak in their voices through the living. ${ }^{113}$

One first understands the "what" about an ancestor and then the "who." Learning the "who" requires effort in genealogical research but also study of the social and historical milieu of the ancestor. A name unattached to associations and without knowledge of the implications of naming is missing aspects of the person. A name is a reference to a specific person who passed a rich legacy on to descendants before passing on from life. That name belongs to a deceased person. A name takes on memorial-sign significance similar to the way a gravestone points to a person.

\section{How This Relates to Psychology}

It was stated earlier that one meaning of the word identity in genealogy is a unique person and that when genealogists write, say, or think a name they are using the name to refer to an identity. As mentioned also, Mill thought that a proper name was strictly denotative, that is, it does not connote. Building on these thoughts, French psychoanalyst Julia Kristeva observes that a proper name does not signify. ${ }^{114,115}$ The proper name is a mark of a "one," a unique identity, which as such cannot be a signifier and thus has no signified. The person who is named is not signified (not to be discussed herein is whether the corpse can be signified by the gravestone). A personal proper name brings with it a network of signifieds that encompass many aspects of and are associated with the genealogical identity-physical, ideological, emotional, social, psychological, and others. Thus the marker of the genealogical name allows the genealogist who writes, speaks, or thinks of the identity 
to "represent" as signs the many experiences and attributes of that identity to find signification. ${ }^{116}$ The more one learns about an ancestor, the more the network of signs widens. In genealogical use the personal name thus finds implicit nameability in what language is unable to "name," or signify. This is what in psychoanalytic terms Kristeva refers to as "borderline discourse" that will "always keep its status as a scar between unnameable meaning on the one hand, and the empty signifier on the other. This is the scar which constitutes the category of the Proper Name." ${ }^{117}$ Walter Benjamin wrote "the name is the translation of the mute into sound and of the nameless into the name." ${ }^{118}$

The oblivion that threatens the dead is a forgetfulness, or loss, of not being remembered, of leaving no trace, of not being named. The living aim to avoid this oblivion for themselves by leaving traces-deeds, products, creations, words, and children. This avoidance is often of higher priority than the avoidance of death. Oblivion is more to be circumvented than death itself. The death of and in oblivion turns one toward the relatively less impactful personal death. That may be the reason that Argentinian novelist Macedonio Fernández wrote "that's why we do a lot more to avoid being forgotten than to avoid dying. ${ }^{119}$ People want to be remembered after their death. It is important to them that they leave a lasting positive impact on others and in the world. People leave traces of themselves in their deeds, products, expressions of feelings, documents, and notes.

\section{Conclusion}

Genealogical practice aims to discover and record names. Almost all of those names are of dead ancestors and their families. This necronominalism has many aspects and implications that were explored herein. Genealogy is about death and names. Naming is central to genealogical practice but what is implied by genealogical naming merits reflection that brings to the surface deep significance for the discipline of genealogy.

A name is first received by an infant soon after birth or at a baptism that signals acceptance of the baby into the family and society. After death, obituaries name the dead person and summarize some aspects of the life of the person. Funerary practices aim to remember and name the lost person, and to help social groups to which the person belonged recover by acknowledging the loss, help each other adjust, and remember and name the dead person.

Gravestones name the dead and thus lead to remembering them. A gravestone is a complex sign pointing down to the corpse, back in time to the departed person buried below, and it also serves as a kind of self-reference in its role as a sign. The marker and the name are cenotaphs for the referenced person.

Naming the deceased is connected to memory. Likewise a momento mori, the materiality of artefacts owned and used by the deceased, and the medieval liber memorialis bring to mind the deceased by naming and evoking the dead person. If we do not name the dead they pass into oblivion. Some have already passed into oblivion but by naming them the careful genealogist helps recover their past existence to reverse the disappearance. An undiscovered ancestor is an unnamed and therefore unknown ancestor. Discovering surviving records in which they appear enables the genealogist to recover their place in the family.

Historical consciousness depends to a degree on whether the genealogist's perspective is centered on the person whose ancestors are named or on descendants of an ancestor. Charts are viewed differently by different researchers.

Discovery of ancestors' names contributes to a person's sense of identity. That includes social and emotional as well as genealogical identity.

Political erasure results in a loss of death, of names, and of the existence of people who disappeared into the void of the state's extralegal processes. This is the opposite of genealogy's drive to name and to remember. The sovereign erases the dead. The genealogist names the dead.

In naming and remembering the dead, one includes them in one's genealogical knowledge and pedigree charts. But in some cases the perspective is not just of inclusion but of exclusion. People are excluded from kin and heritage on the basis of social and economic class, ethnicity, and race, and this viewing kinship based on social group membership inflicts ethical harm. The exclusionary perspective paints some groups as desirable and others as less desirable.

Genealogical practitioners relate to naming the dead in different ways. Many collect names without connecting the people shown on charts to real people. They are names of people who are often incorrectly identified. Others correctly identify names with specific people but some fail to recognize the significance of names as they relate to cultural history, signification, the connection to artefacts and writing, and how one rescues them from oblivion. 


\section{References}

1 MacLeod, Christopher. (2016) John Stuart Mill. Standard Encyclopedia of Philosophy, section 3.1. plato.stanford.edu/entries/mill/.

2 Cumming, Sam. (2019) Names. Standard Encyclopedia of Philosophy, sections 2.2, 2.5. plato.stanford.edu/entries/names/.

3 Koon, Fred and Alberto Voltolini. (2018) Fictional entities. Standard Encyclopedia of Philosophy, section 2.1.1. plato.stanford.edu/entries/fictional-entities/.

4 Ludlow, Peter. (2018) Descriptions. Standard Encyclopedia of Philosophy, section 4.1. plato.stanford.edu/entries/descriptions/\#DesTheProNam/.

5 Michaelson, Eliot. (2019) Reference. Standard Encyclopedia of Philosophy, sections 2.2, 2.3. plato.stanford.edu/entries/reference/.

6 Michaelson, Eliot. (2019) Reference. Standard Encyclopedia of Philosophy, section 2.3. plato.stanford.edu/entries/reference/.

7 Laqueur, Thomas W. (2015) The Work of the Dead: A Cultural History of Mortal Remains. Princeton: Princeton University Press. p. 367.

8 Metcalf, Peter and Richard Huntington. (1991) Celebrations of Death: The Anthropology of Mortuary Ritual. $2^{\text {nd }}$ ed. Cambridge: Cambridge University Press. p. 36.

9 Laqueur. The Work of the Dead. p. 10

10 Harrison, Robert Pogue. (2003) The Dominion of the Dead. Chicago: The University of Chicago Press, pp. 56, 59, 62.

11 Williams, Howard M. R. (2005) Keeping the Dead at Arm's Length. Journal of Social Archaeology. Vol. 5. No. 2. pp. 253-75 (254).

12 Cole, Susan Letzler. (1985) The Absent One: Mourning Ritual, Tragedy, and the Performance of Ambivalence. University Park: The Pennsylvania State University Press. p. 8.

13 Hallam, Elizabeth and Jenny Holkey. (2001) Death, Memory and Material Culture. Oxford: Berg. p. 50.

14 Gadamer, Hans-Georg. (1981) Reason in the Age of Science. Translated by Frederick G. Lawrence. Cambridge: The MIT Press. p. 75.

15 Williams, Keeping the Dead at Arm's Length. pp. 256-57, 264.

16 Pearson, Mike Parker. (2000) The Archaeology of Death and Burial. College Station: Texas A\&M University Press. p. 158.

17 Pearson, The Archaeology of Death and Burial. p. 158.

18 Verdery, Katherine. (1999) The Political Lives of Dead Bodies: Reburial and Postsocialist Change. New York: Columbia University Press. p. 28

19 Harrison, The Dominion of the Dead. p. 15.

20 An Intermediate Greek-English Lexicon. (1991) [based on Liddell and Scott's $7^{\text {th }}$ ed.] Oxford: At the Clarendon Press, oñ $\mu$ a, q.v., def. 1: "sign, mark, token;" def. 4: "sign by which a grave is known;" def. 5: "a token by which any one's identity was certified."

21 Harrison. The Dominion of the Dead. p. 20.

22 Genette, Gérard. (1995) Mimologics. Translated by Thaïs E. Morgan. Lincoln: University of Nebraska. pp. 14-15, 18.

23 Danker, Frederick William, ed. (2000) A Greek-English Lexicon of the New Testament and Other Early Christian Literature. $3^{\text {rd }}$ ed. [BDAG]. Chicago: The University of

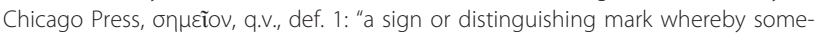

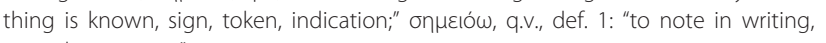
note down, write."

24 Harrison. The Dominion of the Dead. p. 20.

25 Harrison. The Dominion of the Dead. p. 20.

26 Harrison. The Dominion of the Dead. p. 21.

27 Harrison. The Dominion of the Dead. p. 21.

28 Harrison. The Dominion of the Dead. p. 65

29 Hegel wrote "Jedes Thier hat im gewaltsamen Tode eine Stimme; spricht sich als aufgehobnes Selbst aus" ("Every animal has a voice in its violent death; it expresses itself as a sublated self;" Hegel, Georg Wilhelm Friedrich. Jenaer Systementwürfe III. Vol. 8 of Gesammelte Werke. (1976) Hamburg: Felix Meiner Verlag. p. 170).

30 Hegel, G. W. F. (1977 [1807]) Phenomenology of Spirit. Translated by A. V. Miller. Oxford: Oxford University Press. pp. 12, 36, 51.

31 Laqueur. The Work of the Dead. p. 42.

32 Jones, Andrew. (2007) Memory and Material Culture. Cambridge: Cambridge University Press. p. 65.

33 Allan, George. (1986) The Importances of the Past: A Meditation on the Authority of Tradition. Albany: State University of New York Press. p. 7.

34 Jones. Memory and Material Culture. p. 67.

35 Harrison. The Dominion of the Dead. p. 92

36 For the corpse as icon, see Laqueur. The Work of the Dead. p. 83

37 Tarlow, Sarah. (1999) Bereavement and Commemoration: An Archaeology of Mortality. Oxford: Blackwell Publishers. p. 20.
38 Allan. The Importances of the Past. p. 6.

39 Runia, Eelco. (2006) Spots. History and Theory. Vol. 45, pp. 305-16 (310).

40 Laqueur. The Work of the Dead. pp. 365, 417.

41 Pearson. The Archaeology of Death and Burial. p. 141.

42 Hallam and Holkey. Death, Memory and Material Culture. p. 3.

43 Küchler, Susanne. (1999) The Place of Memory. In The Art of Forgetting. Edited by Adrian Forty and Susanne Küchler. Oxford: Berg. p. 68.

44 Hallam and Holkey. Death, Memory and Material Culture. pp. 26, 49.

45 Hallam and Holkey, Death, Memory and Material Culture, pp. 49-50.

46 Jones. Memory and Material Culture. pp. 19-26.

47 Hallam and Holkey. Death, Memory and Material Culture. p. 75.

48 Jones. Memory and Material Culture. p. 69.

49 Hallam and Holkey. Death, Memory and Material Culture. p. 121.

50 Pearson. The Archaeology of Death and Burial. p. 144.

51 Marx, Karl. (1976 [1867]) Capital: A Critique of Political Economy. Translated by Ben Fowkes. London: Penguin Books. Vol. 1. p. 165.

52 Marx. Capital: A Critique of Political Economy. p. 165.

53 Marx. Capital: A Critique of Political Economy. pp. 164-65.

54 Lukács, Georg. (1971) History and Class Consciousness: Studies in Marxist Dialectics. Translated by Rodney Livingstone. Cambridge: The MIT Press. p. 84.

55 Riffaterre, Michael. (1990) Fictional Truth. Baltimore: The Johns Hopkins University Press. pp. 31, 45.

56 Laqueur. The Work of the Dead. p. 94.

57 Laqueur. The Work of the Dead. p. 383.

58 Laqueur. The Work of the Dead. p. 384.

59 Harrison. The Dominion of the Dead. p. ix.

60 Harrison. The Dominion of the Dead. p. xi.

61 Harrison. The Dominion of the Dead. p. ix.

62 Debray, Régis. (2000) Transmitting Culture. Translated by Eric Rauth. New York: Columbia University Press.

63 Harrison. The Dominion of the Dead. p. x.

64 Laqueur. The Work of the Dead. p. 17.

65 Allan. The Importances of the Past. p. 77.

66 Personal observation during travel in Mexico.

67 Conversations with native Mexicans.

68 Paz, Octavio. (1961) Labyrinth of Solitude: Life and Thought in Mexico. Translated by Lysander Kemp. New York: Grove Press.

69 Clymes, Tom. (1995) Wild Planet! 1,001 Extraordinary Events for the Inspired Traveler. Detroit: Visible Ink. pp. 543-45.

70 Ward, Logan. (2017) Top 10 Things to Know about the Day of the Dead. nationalgeographic.com/Travel/destinations/north-america/mexico/top-ten-day-ofdead-mexico/

71 Domínguez Fernández, Esther Guadalupe. (2019) "Origen y Evolución del Día de los Muertos Mexicano." Lecture delivered at the Biblioteca Pública Municipal Iván de Vargas, Madrid, Spain, as related by an attendee.

72 Pearson. The Archaeology of Death and Burial. p. 145.

73 Bouquet, Mary. (2000) Figures of Relations: Reconnecting Kinship Studies and Museum Collections. In Cultures of Relatedness: New Approaches to the Study of Kinship. Edited by Janet Carsten. Cambridge: Cambridge University Press. pp. 16790 (186).

74 Bouquet, Mary. (2001) Making Kinship with an Old Reproductive Technology. In Relative Values: Reconfiguring Kinship Studies. Edited by Sarah Franklin and Susan McKinnon. Durham: Duke University Press. pp. 85-115 (98).

75 Verdery. The Political Lives of Dead Bodies: Reburial and Postsocialist Change. p. 117.

76 Erben, Michael. (1991) Genealogy and Sociology: A Preliminary Set of Statements and Speculations. Sociology. Vol. 25. No. 2. pp. 275-92 (276).

77 Owusu-Bempah, Kwame. (2007) Children and Separation: Socio-Genealogical Connectedness Perspective. London: Routledge. pp. 23, 33.

78 Nicolson, Paula. (2017) Genealogy, Psychology and Identity: Takes from a Family Tree. London: Routledge. p. 15.

79 Brubaker, Rogers. (2004) Ethnicity without Groups. Cambridge: Harvard University Press.

80 Jones. Memory and Material Culture. p. 70.

81 Gadamer. Reason in the Age of Science. p. 75.

82 Laqueur. The Work of the Dead. pp. 50, 372.

83 Tarlow. Bereavement and Commemoration. p. 131.

84 Barley, Nigel. (1997) Grave Matters: A Lively History of Death around the World. New York: Henry Holt and Company. p. 151. 
85 Bargu, Banu. (2014) Sovereignty as Erasure: Rethinking Enforced Disappearances. Qui Parle. Vol. 23. No. 1. pp. 35-75 (35-39).

86 Bargu. Sovereignty as Erasure. p. 39.

87 Bargu. Sovereignty as Erasure. p. 42

88 Bargu. Sovereignty as Erasure. p. 44.

89 See Gordon, Avery. (2008) Ghostly Matters: Haunting and the Sociological Imagination. Minneapolis: University of Minnesota Press. p. 80.

90 Bradley, Arthur. (2019) Unbearable Life: A Genealogy of Political Erasure. New York: Columbia University Press. p. 2

91 Bradley. Unbearable Life. p. 2.

92 Bargu. Sovereignty as Erasure. p. 61.

93 Bradley. Unbearable Life. p. 3.

94 Bradley. Unbearable Life. p. 5.

95 Damian, Peter. (1998) Letters 91-120. Translated by Owen J. Blum. The Fathers of the Church Mediaeval Continuation; Washington: The Catholic University of America Press. p. 383.

96 Laqueur. The Work of the Dead. p. 373.

97 Hatton, Stephen B. (2019) History, Kinship, Identity, and Technology: Toward Answering the Question "What Is (Family) Genealogy?' pp. 4-5. Genealogy 3, 2 https://doi.org/10.3390/genealogy3010002.

98 Laqueur. The Work of the Dead. p. 366.

99 Laqueur. The Work of the Dead. p. 415.

100 Laqueur. The Work of the Dead. p. 412.

101 Hackstaff, Karla. Genealogy as Social Memory: Making the Public Personal. pp. 1-32 2). www.newschool.edu/nssr/historymattters/papers/KarlaHackstaff.pdf.

102 Kramer, Anne-Marie. (2011) Kinship, Affinity and Connectedness: Exploring the Role of Genealogy in Personal Lives. Sociology. Vol. 45. pp. 379-95.
103 Bottero, Wendy. (2012) Who Do You Think They Were? How Family Historians Make Sense of Social Position and Inequality in the Past. The British Journal of Sociology. Vo. 63. pp. 54-74.

104 Zerubavel, Eviatar. (2012) Ancestors and Relatives: Genealogy, Identity, and Continuity. Oxford: Oxford University Press.

105 Sleeter, Christine E. (2016) Critical Family History: Situating Family within Contexts of Power Relationships. Journal of Multidisciplinary Research. Vol. 8. pp. 11-23.

106 Hackstaff. Genealogy as Social Memory. pp. 3, 8.

107 Gordon. Ghostly Matters. pp. 11, 17, 72-77, 126-27.

108 Clément, Catherine. (1986) Sorceress and Hysteric. In Hélène Cixous and Catherine Clément. The Newly Born Woman. Translated by Betsy Wing. Minneapolis: University of Minnesota Press. p. 6

109 Nash, Catherine. (2004) Genetic Kinship. Cultural Studies. Vol. 18. pp. 1-33 (16).

110 Hackstaff. Genealogy as Social Memory. p. 1.

111 Kramer. Kinship, Affinity and Connectedness: Exploring the Role of Genealogy in Personal Lives. p. 20.

112 Williams, Bernard. (2002) Truth \& Truthfulness: An Essay in Genealogy. Princeton: Princeton University Press. pp. 11, 14.

113 Harrison. The Dominion of the Dead. p. 151

114 Kristeva, Julia. (1996) Name of Death or of Life. In Writing and Psychoanalysis: A Reader. Edited by John Lechte. London: Arnold. pp. 103-16 (111).

115 Genette. Mimologics. pp. 16-17.

116 Kristeva. Name of Death or of Life. pp. 111-12.

117 Kristeva. Name of Death or of Life. p. 112.

118 Benjamin, Walter. (1999) Selected Writings. Volume 2, Part 2 1931-1934. Translated by Rodney Livingstone. Cambridge: Harvard University Press. p. 717

119 Fernández, Macedonio. (2010) The Museum of Eterna's Novel (The First Good Novel). Translated by Margaret Schwartz. Rochester: Open Letter. p. 36.

\section{ABOUT THE AUTHOR}

Stephen B. Hatton is on the editorial board of Genealogy, an international scholarly open-access journal. He is a trustee and technology committee chair of the Ohio Genealogical Society (www.ogs.org). He is interested in genealogical research, methodology, and theory. 